\title{
MENELISIK KESIAPAN SUMBER DAYA MANUSIA NON KESEHATAN DALAM MENDUKUNG PELAYANAN RUMAH SAKIT DI ERA NEW NORMAL
}

\author{
I Wayan Suwira* ${ }^{*}$ Ida Ayu Oka Martini ${ }^{2}$ \\ Universitas Pendidikan Nasional Denpasar ${ }^{12}$ \\ e-mail: ${ }^{1}$ suwiraiwayan@yahoo.co.id
}

\begin{abstract}
The readiness of Human Resources is an important element of the success of the Hospital organization in providing good health services to Covid-19 patients. Non-Health Workers are competent workers who must be ready to face the Services in the New Era. The purpose of this study is to see how the readiness of non-health human resources in supporting hospital services in the New Era is normal. The type of research used is a case study using a qualitative descriptive research approach with data collection techniques: in-depth interviews and documentation. Data processing in this study uses thematic analysis. The results of the study indicate that socialization or fair information about the Covid-19 disease intensively, carrying out continuous evaluations and ensuring the implementation of the Director's policy regarding the application of health protocols at work and the budgeting policy for the provision of Personal Protective Equipment greatly affect the Readiness of NonHealth Human Resources in supporting services. Hospitals in the New Era are normal. This is in accordance with the technical guidelines for hospital services during the adaptation period of new habits issued by the Indonesian Ministry of Health in 2020 that hospital administrators prepare service management according to national health protocol standards by prioritizing health and safety by preventing and controlling the transmission of COVID-19 so that can provide protection for human resources in hospitals. It is recommended that regularly socialize the application of health protocols on an ongoing basis, carry out monitoring and evaluation in stages.
\end{abstract}

Keywords: human resources readiness, successful implementation, hospital, new normal

\begin{abstract}
ABSTRAK
Kesiapan Sumber Daya Manusia menjadi elemen penting keberhasilan organisasi Rumah Sakit dalam memberikan pelayanan kesehatan yang baik kepada pasien Covid-19. Tenaga Non Kesehatan adalah tenaga yang kompeten yang harus siap menghadapi Pelayanan di Era Baru. Tujuan dari penelitian ini adalah untuk melihat bagaimana kesiapan SDM non kesehatan dalam mendukung pelayanan rumah sakit di Era Baru sudah normal. Jenis penelitian yang digunakan adalah studi kasus dengan menggunakan pendekatan penelitian deskriptif kualitatif dengan teknik pengumpulan data: wawancara mendalam dan dokumentasi. Pengolahan data dalam penelitian ini menggunakan analisis tematik. Hasil penelitian menunjukkan bahwa sosialisasi atau informasi yang adil tentang penyakit Covid-19 secara intensif, melakukan evaluasi terus menerus dan memastikan implementasi kebijakan Direktur tentang penerapan protokol kesehatan di tempat kerja dan kebijakan penganggaran untuk penyediaan Alat Pelindung Diri sangat mempengaruhi Kesiapan SDM Non Kesehatan dalam pelayanan penunjang. Rumah Sakit di Era Baru itu normal. Hal ini sesuai dengan petunjuk teknis pelayanan rumah sakit pada masa adaptasi kebiasaan baru yang dikeluarkan oleh Kementerian Kesehatan RI tahun 2020 bahwa pengelola rumah sakit mempersiapkan manajemen pelayanan sesuai standar protokol kesehatan nasional dengan mengutamakan kesehatan dan keselamatan dengan mencegah dan mengendalikan penularan. COVID-19 sehingga dapat memberikan perlindungan bagi sumber daya manusia di rumah sakit. Disarankan secara berkala mensosialisasikan penerapan protokol kesehatan secara berkesinambungan, melakukan monitoring dan evaluasi secara bertahap.
\end{abstract}

Kata kunci: kesiapan sumber daya manusia, keberhasilan implementasi, rumah sakit, new normal 


\section{PENDAHULUAN}

Coronavirus Disease (Covid-19) pada awal tahun 2020 menjadi masalah kesehatan dunia, penyebaran Covid 19 membawa dampak diberbagai sector. Apabila masa pandemi ini berlangsung dalam kurun waktu yang panjang maka, membawa kerugian pada perkonomian yang meliputi kerugian nasional, sectoral, corporate dan individual. Upaya pemerintah menekan penyebaran Covid 19 dengan melaksanakan kehidupan normal baru (new normal) salah satunya di lingkungan pelayanan kesehatan di Rumah Sakit. Rumah Sakit menjadi benteng terakhir dalam perlawanan terhadap COVID-19. Bagi pasien kasus sedang dan berat yang memerlukan layanan intensif dengan segala keterbatasan, Rumah Sakit diharapkan mampu mengoptimalkan seluruh sumber daya yang dimiliki dalam menghadapi pandemi COVID-19.

Masa Adaptasi Kebiasaan Baru diartikan sebagai perubahan perilaku bagi Rumah Sakit untuk tetap menjalankan aktivitas normal. Pelayanan kesehatan sebagai sektor yang paling terdampak oleh situasi pandemik ini juga harus bersiap untuk menghadapi adaptasi kebiasaan baru. Rumah Sakit harus mulai memikirkan langkah-langkah yang akan diambil untuk tetap merawat pasien COVID-19 namun disaat bersamaan juga dapat memberikan pelayanan kepada pasien non COVID-19 dengan risiko penularan seminimal mungkin dengan menerapkan Pencegahan dan Pengendalian Infeksi

Kesiapan Sumber Daya Manusia (SDM) dan sarana prasarana merupakan unsur penting kesuksesan organisasi Rumah Sakit dalam memberikan layanan kesehatan baik kepada pasien Covid-19 maupun Non Covid-19. Sumber Daya Manusia dalam menopang pelayanan dirumah sakit terdiri tenaga non kesehatan (non medis dan non paramedis) adalah tenaga kesehatan yang tidak langsung berhubungan dengan pasien misalnya bagian umum yang meliputi Administrasi, Satpam dan Clening Service (CS), Loundry, dan Central Sterilisasi Suplay Departemen (CSSD). Namun demikian tidak semua tenaga non kesehatan rumah sakit memiliki tingkat pemahaman, perilaku dan kebiasaan dalam menghadapi kebiasaan baru. Dengan demikian dibutuhkan usaha dalam merubah kebiasaan ini sehingga seluruh tenaga non kesehatan terbiasa mengikuti protocol kesehatan yang ditetapkan pemerintah. Hal ini juga harus diimbangi dengan perubahan terhadap perbaikan standar operasional prosedur dan lain sebagainya.

Mempersiapkan sdm NON kesehatan agar siap berubah pada organisasi maka diperlukan pemahaman mengenai cara yang dapat digunakan dalam menumbuhkan kesiapan untuk merubah. Kesiapan ini sangat bergantung pada tingkat pengetahuan yang dimiliki oleh tenaga non kesehatan. Namun, pengetahuan tentang covid 19 yang dimiliki sering kali terabaikan karena ketidak sengajaan ataupun ketidakbiasaan tenaga non kesehatan dalam melaksanakan tugasnya
Tenaga Non Kesehatan merupakan tenaga kerja kompeten yang harus siap menghadapi Pelayanan di Era Baru. Sebagai tenaga pendukung pelayanan di rumah sakit dan fungsi Tenaga Non Kesehatan tersebut harus di Upgrade dalam menghadapi era perubahan di tengah-tenga masa pendemi. Dalam tenaga Non Kesehatan harus selalu melakukan antispasi penularan terhadap dirinya sendiri dan pengguna layanan dengan penerapan prosedur Pencegahan dan Pengendalian Infeksi (PPI), penerapan Keselamatan dan Kesehatan Kerja (K3) di unit kerja dan pemenuhan Alat Pelindung Diri (APD). Penelitian ini bertujuan untuk memperoleh gambaran Kesiapan Sumber Daya Manusia Non Kesehatan dalam mendukung pelayanan Rumah Sakit di Era Baru.

\section{METODE}

Jenis penelitian yang digunakan adalah studi kasus menggunakan pendekatan penelitian deskriptif kualitatif dengan pendekatan induktif. Penelitian ini akan dilaksanakan di RSUD Kabupaten Klungkung. Sampel yang terdiri dari orang-orang (disebut informan) akan ditentukan berdasarkan teknik sampling purposive dengan menggunakan criterion based selection, dimana jumlah informan ditetapkan sendiri oleh peneliti berdasarkan pertimbangan tertentu yaitu jumlah informan adalah 6 responden yaitu 2 orang dari manajemen dan 4 orang tengan non kesehatan teridiri dari petugas cleaning service, petugas administrasi, petugas loundry dan petugas pemulasaraan jenasah. Tehnik pengumpulan data menggunakan Wawancara mendalam dan dokumentasi. Pengolahan data dalam penelitian ini menggunakan analisis tematik.

\section{HASIL}

Peneliti mendeskripsikan data yang diperoleh dari wawancara mendalam tentang kesiapan sumber daya manusia (SDM) non kesehatan dalam mendukung pelayanan rumah sakit di era new normal. Peneliti telah mewawancarai beberapa informan, yaitu orang dari manajemen dan 4 orang tengan non kesehatan. Informan pertama adalah Direktur Rumah Sakit Umum Klungkung. Peneliti bertemu dengan informan pada pada tanggal 5 Juni 2021. Peneliti menjelaskan tujuan penelitian. Peneliti memberikan lembar informasi dan persetujuan sebagai informan, dan Bapak Direktur membaca dengan serius isi lembar dan menandatangani formulir persetujuan sebagai informan. Peneliti menjelaskan bahwa selama wawancara proses perekaman suara dan pengambilan foto akan dilakukan di akhir wawancara sebagai dokumen bahwa wawancara itu memang dilakukan. Selanjutnya peneliti melakukan proses wawancara dengan mengajukan pertanyaan kepada Bapak Direktur tentang kebijakan-kebijakan yang dilakukan 


\section{Vol. 16 No.2 Mei - Agustus 2021}

sebagai upaya mempersiapkan SDM terutama Non Kesehatan dalam mendukung pelayanan Rumah Sakit di era new normal, beliau memaparkan bahwa menyiapkan SDM non kesehatan pada Era New Normal sangat penting dilakukan agar mereka mampu memberikan dukungan terhadap pelayanan kesehatan sehingga ketakutan dan kekhawatiran akan tertular dapat di minimalkan agar tidak berdampak terhadap kinerja mereka " Kebijakan yang sudah dibuat untuk mempersiapkan SDM non kesehatan antara lain SDM non kesehatan kita berikan sosialisasi untuk mencegah penularan covid 19 tentang penggunaan Alat pelindung Diri, beberapa alur pelayanan yang dilaksanakan oleh SDM non kesehatan untuk mendukung pelayanan covid-19. Informan 2 yaitu Kepala Bagian Umum dan Pengembangan SDM RSUD Klungkung. Peneliti bertemu dengan informan pada pada tanggal 6 Juni 2021. Hasil Wawancara diperoleh "Strategi yang dilakukan untuk mengawal kebijakan penerapan protokol kesehatan saat bekerja dengan melaksanakan sosialisasi penerapan protokol kesehatan secara berkesinambuhan, melakukan monitoring dan evaluasi secara berjenjang. Sedangkan hasil wawancara dengan 4 orang tenaga non kesehatan didapatkan hasil yang sama yaitu "Kebijakan agar semua staf dalam bekerja saat ini menerapkan protokol kesehatan salah satunya menggunakan APD”, upaya yang dilakukan sangat membantu kesiapan sumber daya manusia non kesehatan dalam mendukung pelayanan rumah sakit di era baru karena dengan penerapan protokol kesehatan, penggunaan APD dan penularan penyakit Covid membuat SDM non kesehatan memahami jika bekerja dengan mematuhi protokol kesehatan dapat terhindar dari penularan covid 19'Kebiasaan menggunakan APD menjadi kendala yang dihadapi dalam penerapan kebijakan penerapan protokol kesehatan saat bekerja.

\section{PEMBAHASAN}

Kualitas pelayanan kepada masyarakat harus tetap terjaga, Rumah Sakit Umum Daerah Klungkung dituntut tetap memberikan pelayanan terbaik meskipun di lain sisi harus menjalankan himbauan protokol kesehatan demi keselamatan bersama, sebagai pelayanan di Bidang Kesehatan, maka Rumah Sakit Umum Daerah Klungkung tidak bisa pemberlakuan WFH (Work from Home) sehingga semua pegawai tetap bekerja seperti biasanya baik SDM kesehatan maupun Non Kesehatan.

Pegawai non kesehatan keberadaan sangat diperlukan untuk membantu kelancaran proses pelayanan, walau mereka tidak berhadapan langsung dengan pasien namun tetap miliki resiko tertular karena paparan lingkungan perawatan pasien Covid juga memiliki resiko penularan, sehingga mereka berisiko lebih tinggi terinfeksi, bekerja di bawah tekanan ekstrem, terpapar stres tinggi, waktu kerja yang lama, beban kerja yang berlebihan, kadang-kadang tanpa pelatihan yang tepat dan peralatan perlindungan pribadi yang memadai. Menghadapi kondisi tersebut diperlukan upaya-upaya dari pimpinan Rumah Sakit untuk mempersiapkan SDM non kesehatan bekerja dalam memberikan dukungan terhadap pelayanan sehingga mereka mampu beradaptasi pada era new normal.

Menelisik kesiapan sumber daya manusia non kesehatan dalam mendukung pelayanan rumah sakit di era new normal, berdasarkan hasil wawancara dengan Direktur RSUD Kabupaten Klungkung, upaya yang sudah dilakukan untuk mempersiapkan sumber daya manusia non kesehatan dalam mendukung pelayanan rumah sakit di era new normal adalah dengan membuat kebijakan bekerja dengan menerapakan protokol kesehatan diantaranya wajib menggunakan APD saat bekerja serta SDM non kesehatan diberikan sosialisasi untuk mencegah penularan covid 19 tentang penggunaan Alat pelindung Diri, perubahan prosedur kerja dan melakukan monitoring dan evaluasi secara berjenjang. Hal tersebut juga diungkapkan oleh Kepala Bagian Umum dan SDM RSUD Klungkung bahwa upaya mempersiapkan SDM non kesehatan bekerja dalam era new normal antara lain kebijakan penerapan protokol kesehatan saat bekerja seperti penggunaan APD untuk SDM non kesehatan saat memberikan pelayanan seperti wajib menggunakan masker, mencuci tangan sebelum dan setelah bekerja dan menjada menjaga jarak, disamping melakukan komunikasi dan koordinasi diantara bidang.

Berdasarkan peraturan Menteri Kesehatan Republik Indonesia nomor 52 tahun 2018 tentang keselamatan dan kesehatan kerja di fasilitas pelayanan kesehatan disebutkan bahwa fasilitas kesehatan wajib menyediakan APD dan penyusun pedoman tentang penggunaan yang aman, memastikan cara penggunaan yang benar. Sesuai dengan panduan teknis pelayanan rumah sakit pada masa adaptasi kebiasaan baru yang dikeluarkan oleh Direktorat Jenderal Pelayanan Kesehatan Kementerian Kesehatan RI tahun 2020 bahwa penyelenggara (Pemilik dan Pengelola) Rumah Sakit dalam mempersiapkan manejemen layanan yang sesuai standar protokol kesehatan nasional dan mendukung produktivitas kerja namun tetap memprioritaskan kesehatan dan keselamatan dengan pencegahan dan pengendalian transmisi COVID-19 sehingga dapat memberikan perlindungan terhadap keselamatan pasien, masyarakat, lingkungan Rumah Sakit dan sumber daya manusia di Rumah Sakit dengan mengikuti protokol kesehatan yang ada (menerapkan pola hidup bersih sehat, menjaga jarak dan mengurangi kontak fisik dengan orang lain, dan lainnya) untuk menghindari penularan dan penyebaran virus

Sejalan dengan Penelitian Syahyuti (2020) mengenai upaya menekan dampak pandemi covid-19 pada sumber daya manusia pertanian di era new normal dilakukan dengan membatasi mobilisasi, penerapan protokol kesehatan dan sosialisasi sehingga terbentuk 
sikap dan perilaku baru bekerja dalam era new normal. Penelitian Rohman (2020) tentang standart pelayanan publik di era transisi new normal. Hasil penelitian menunjukkan bahwa Bapenda Kota malang telah menjalankan standart pelayanan dengan menggunakan protokol kesehatan. Upaya yang dilakukan adalah dengan penerapkan protokol keseahatan dalam bekerja, mengurangi jumlah pegawai yang bertugas, pemenuhan sarana dan prasarana pelayanan sesuai protokol kesehatan. Hasil penelitian ini juga mengungkapkan kurangnya kesadaran pegawai dalam mentaati protokol kesehatan.

Kesiapan sumber daya manusia non kesehatan dalam mendukung pelayanan rumah sakit di era new normal, berdasarkan hasil wawancara dengan beberapa pegawai non kesehatan yang menjadi informan menunjukkan bahwa dengan adanya kebijakan direktur tentang pelayanan di era new normal dengan menerapakan protokol kesehatan serta sosialisasi yang diberikan terkait penularan Covid 19 membuat mereka siap bekerja untuk mendukung pelayanan rumah sakit di era new normal karena mengetahui bahwa penularan covid bisa di cegah dengan menerapkan protokol kesehatan.

Kebijakan Pemerintah yang terbaru dengan meminta masyarakat untuk "berdamai" dengan Covid19 dengan menggaungkan apa yang disebut New Normal atau Pola Hidup Baru tentunya tidak terlepas dari upaya yang telah dilakukan oleh pemerintah selama ini dalam menangani penyebaran Covid-19. Tatanan hidup baru dengan menerapkan protokol kesehatan bukan berarti kembali hidup dalam keadaan sebelum pandemi terjadi. Kebiasaan mencuci tangan pakai sabun, mengenakan masker, menjaga jarak fisik termasuk menjaga daya tahan tubuh wajib dilakukan. Pencegahan dan pengendalian infeksi COVID-19 di fasilitas kesehatan meliputi kontrol administratif, kontrol lingkungan dan teknik, serta alat pelindung diri (APD). Seringkali APD menjadi mekanisme kontrol yang paling terlihat digunakan padahal APD seharusnya digunakan bersama dengan kontrol administratif dan teknis. APD harus dipilih dengan benar dan digunakan dengan cara yang aman. Alat pelindung diri harus digunakan sebelum memasuki ruangan yang terkontaminasi dan hindari untuk menyentuh bagian wajah apabila sudah menggunakan alat pelindung diri. Selalu lakukan higiene tangan sebelum dan setelah menggunakan alat pelindung diri.

Salah satu yang menjadi perlengkapan bagi tenaga non kesehatan adalah penggunaan alat perlindungan diri (APD) yang tepat, akses sanitasi yang layak dan penerapan protocol dalam melakukan pekerjaan (Huang et al., 2020: King and Hothi, 2020). Penggunaan APD harus menjadi kewajiban dan kebiasaan tenaga kerja sebagai perlindungan terakhir dalam upaya pencegahan kecelakaan dan penyakit akibat kerja (PAK).Penggunaan APD tersebut dapat mengurangi resiko paparan penularan penyakit kepada tenaga kerja.Dalam pelaksanaan sistem keselamatan kerja, Rumah Sakit telah menerapkan kewajiban penggunaan APD bagi kesehatan dan keselamatan kerja setiap tenaga kerja atau karyawan yang berada di tempat kerja yang mempunyai potensi dan faktor bahaya tertentu.Hal ini sesuai dengan Kepmenkes No. 1087/MENKES/SK/VIII/2010 tentang standar Kesehatan dan Keselamatan Kerja di rumah sakit.

Pengunaan alat pelindung diri (APD) oleh SDM non kesehatan ditemukan juga kendala, hal ini terungkap dari informasi yang diberikan oleh informan bahwa kendala kebiasaan menggunakan APD seperti tidak leluasa dalam bekerja, sulit bernafas, gerah dan panas. Kondisi ini memerlukan pengawasan dan monitoring untuk meningkatkan kepatuhan dalam bekerja. Pengawasan mempengaruhi kepatuhan pegawai dalam menggunakan APD yang mendukung keselamatan kerja, pengawasan dapat memberikan motivasi bagi pegawai untuk meningkatkan kepatuhan dalam menggunakan alat pelindung diri secara konsisten. Pengawasan merupakan salah satu faktor yang mempengaruhi pegawai dalam menggunakan APD. Proses pengawasan yang dilakukan di Rumah Sakit Umum Daerah Klungkung dilakukan oleh pimpinan unit kerja masing-masing serta secara konsisten melakukan komunikasi dan sosialisasi terkait manfaat penggunaan APD saat bekerja, pengawasan yang dilakukan ini padat meningkatkan pemahaman pegawai tentang pentingnya pengunaan APD untuk mencegah penularan serta mingkatkan kesiapan mereka dalam bekerja untuk mendukung pelayanan di era new normal.

Kendala lain yang dirasakan sebagai hambatan dalam bekerja untuk mendukung pelayanan di era new normal yang menjadi harapan SDM non kesehatan seperti hasil wawancara dengan informan adalah keselamatan staf saat bekerja menjadi perhatian pimpinan seperti persedian APD cukup dan informasi terbaru tentang penularan Covid 19 selalu diberikan karena informasi tersebut sangat penting untuk mencegah penularan. Seiring pandemi yang semakin cepat, akses ke alat pelindung diri (APD) untuk petugas kesehatan adalah masalah utama. Staf medis diprioritaskan di banyak negara, tetapi terjadi kekurangan APD sebagai fasilitas yang paling penting. Ketersediaan fasilitas merupakan salah satu faktor yang mempengaruhi terbentuknya kepatuhan. Ketersediaan alat pelindung diri di tempat kerja harus menjadi perhatian pihak manajemen rumah sakit dan tenaga kesehatan untuk mendorong terjadinya perubahan sikap. Semua fasilitas alat pelindung diri yang diwajibkan pada tenaga kesehatan harus tersedia sesuai dengan risiko bahaya yang ada di tempat kerja. Sarana fasilitas kesehatan yang lengkap dapat mendukung pembentukan perilaku yang baik dalam menjalankan prosedur kewaspadaan universal. Hal ini sesuai dengan teori yang mengatakan bahwa pembentukan perilaku terjadi melalui 3 domain, yaitu pengetahuan, sikap, dan psikomotor. Walaupun pengetahuan dan sikap yang dimiliki responden sudah cukup baik, tapi tanpa didukung ketersediaan sarana 


\section{Vol. 16 No.2 Mei - Agustus 2021}

yang lengkap tidak akan terbentuk psikomotor berupa perilaku kepatuhan.

\section{KESIMPULAN}

Dari penelitian yang telah dilaksanakan di RSUD Klungkung, hasil penelitian menunjukan kesiapan sumber daya manusia non kesehatan dalam mendukung pelayanan rumah sakit di era baru adalah sebagai berikut: upaya yang dilakukan untuk mempersiapkan sumber daya manusia non kesehatan dalam mendukung pelayanan rumah sakit di era baru dilakukan dengan membuat kebijakan tentang penerapan protokol kesehatan saat bekerja dengan menggunakan APD, sosialisasi penggunaan APD dan penularan Covid 19 dan perubahan beberapa alur pelayanan yang dilaksanakan oleh SDM non kesehatan untuk mendukung pelayanan covid 19. Strategi yang dilakukan untuk mengawal kebijakan penerapan protokol kesehatan saat bekerja dengan melaksanakan sosialisasi penerapan protokol kesehatan secara berkesinambuhan, melakukan monitoring dan evaluasi secara berjenjang. Upaya yang dilakukan sangat membantu kesiapan sumber daya manusia non kesehatan dalam mendukung pelayanan rumah sakit di era baru karena dengan penerapan protokol kesehatan, penggunaan APD dan penularan penyakit Covid membuat SDM non kesehatan memahami jika bekerja dengan mematuhi protokol kesehatan dapat terhindar dari penularan covid 19. Kebiasaan menggunakan APD menjadi kendala yang dihadapi dalam penerapan kebijakan penerapan protokol kesehatan saat bekerja.

\section{DAFTAR PUSTAKA}

1. Ahlstrom, D. et al. (2020) 'Managing Technological, Sociopolitical, and Institutional Change in the New Normal', Journal of Management Studies, 57(3), pp. 411-437. doi: 10.1111/joms. 12569.

2. Budastra, I. K. (2020) 'Dampak Sosial Ekonomi Covid 19 dan Program Potensial Untuk Penanganannya: Studi Kasus di Kabupaten Lombok Barat', Jurnal Agrimansion, 20(1), pp. 48 57.

3. Burhanuddin, C. I. and Abdi, M. N. (2020) 'Ancaman Krisis Ekonomi Global Dari Dampak Penyebaran Virus Corona (Covid 19)', Jurnal Ilmiah, 17(1), pp. 90-98.

4. Hadiwardoyo, W. (2020) 'Kerugian Ekonomi Nasional Akibat Pandemi Covid 19', Journal of Business and Entrepreneurship, 2(2), pp. 83-92. doi: 10.24853/baskara.2.2.83-92.

5. Huang, H. L. et al. (2020) 'Nuclear medicine services after COVID-19: gearing up back to normality', European Journal of Nuclear Medicine and Molecular Imaging. European Journal of Nuclear Medicine and Molecular Imaging, 47, pp. 2048-2053. doi: 10.1007/s00259-020-04848-1.

6. King, L. A. and Hothi, S. S. (2020) 'Remodelling elective hospital services in the COVID-19 era designing the new normal', Future Healthcare Journal, 7(3), p. fhj.2020-0079. doi: 10.7861/fhj.2020-0079.

7. Lee, T. H. (2020) 'Innovations in Care Creating the New Normal: The Clinician Response to Covid19', NEJM Catalyst, pp. 19-21. doi: 10.1056/CAT.20.0076.

8. Luker, G. D. and Boettcher, A. N. (2020) 'Transitioning to a New Normal after COVID-19: Preparing to Get Back on Track for Cancer Imaging', Radiology: Imaging Cancer, 2(3), pp. 113. doi: 10.1148/rycan.2020204011.

9. Muhyiddin (2020) 'Covid-19, New Normal, dan Perencanaan Pembangunan di Indonesia', The Indonesian Journal of Development Planning, 4(2), pp. 240-252. doi: 10.36574/jpp.v4i2.118.

10. Novitasari, D. et al. (2020) 'Mempertahankan Kinerja Karyawan di Masa Pandemi Covid-19: Analisis Kesiapan untuk Berubah dan Efektivitas Kepemimpinan Transformasional', Jurnal Manajemen dan Akuntansi, 15(2), pp. 22-37.

11. Noy, C. (2008) 'Sampling knowledge: The hermeneutics of snowball sampling in qualitative research', International Journal of Social Research Methodology, 11(4), pp. 327-344. doi: 10.1080/13645570701401305.

12. Sulaeman and Supriadi (2020) 'Peningkatan Pengetahuan Masyarakat Desa Jelantik Dalam Menghadapi Pandemi Corona Virus Diseases-19 (Covid-19)', Jurnal Pengabdian UNDIKMA, 1(1), pp. 12-17.

13. Frida Kesumawati,Mochammad Hasan (2020)' Kesiapan Menghadapi New Normal', Jurnal Abdi Masyarakat Vol 1, No. 1

14. Alreshidi,NM,Haridi H,Alseeri R,Gargia M,Gaspar F, (2020), 'Menilai Pengetahuan,Emosi dan Kesiapan yang dirasakan oleh petugas kesehatan tentang Pandemi Covid-19 di Rumah Sakit Saudi pada fase awal Pandemi', Jurnal Penelitian Kesehatan Masyarakat 9, (4)

15. Idah Waidah,Muhamad Andi Septiadi,M.Choerul Adllie Rafqie,Nur Fitria Salsabila Hartono, Raihan Athallah', Pandemi Covid-19: Analisi Perencanaan Pemerintah dalam Masyarakat Berbagai Upaya 
Pencegahan', Jurnal Manajemen dan Organisasi (JMO),Vol.11 No.3,Hal.179-188.

16. Yuliana,(2020),'Corona virus diseases (Covid19)',Jurnal Wellnes And Healthy Magazina,Vol. 2, Nomor 1

17. Kementerian Kesehatan RI,(2020),'Pedoman Kesiapsiagaan menghadapi Infeksi Covid-19', Surat Edaran Dirjen P2P Nomor: HK 02.02/II/753/2020

18. Kementerian Kesehatan RI (2020)',Panduan Teknis Pelayanan Rumah Sakit Pada Masa Adaptasi Kebiasaan baru.

19. Dewi Susanna,(2020),'When Will the COVID-19 Pandemic in Indenesia End?', National Public Health Journal,Vol.15, No.4

20. Sang Gede Purnama, Dewi Susanna,(2020),' Hygiene and Sanitation Challenge for COVID-19 Prevention in Indonesia', National Public Health Journal,Vol.1.

21. Faura Dea Ayu Pinasti,(2020),'Analisis Dampak Pandemi Corana Virus terhadap Tingkat kesadaran Masyarakat dalam Penerapan Protokol kesehatan', Wellness and HealthyMagazine Journal, Vol.2 No. 2

22. Siti Nurhalimah, (2020),' Covid-19 dan Hak Masyarakat atas kesehatan', Jurnal Sosial dan Budaya Syar-1, Vol.7, No.6.

23. Mujiburrahman,Muskhab,Eko Riyadi,Mira Utami Ningsih, (2020),'Hubungan Pengetahuan dengan Prilaku Pencegahan Covid-19 di Masyarakat',Jurnal Keperawatan Terpadu,Vol.2, No.2.

24. Ayu Riana Sari (dkk).(2020).'Prilaku Pencegahan Covid-19 Ditinjau dari Karakteristik Individu dan
Sikap Masyarakat'.Jurnal Penelitian dan Pengembangan Kesehatan Masyarakat Indonesia.Vol.1.No.1.

25. WHO.(2020).'Advice on the use of masks in the contex of COVID-19'.sumber Website infeksi Emerging,WHO.

26. Kementerian Kesehatan RI,(2020).'Komunikasi penanganan Corrona Virus Deasess (Covid-19)', Surat Edaran Menteri Kesehatan Nomor: HK 02.01/MENKES/199/2020

27. Marwansyah (2019).'Manajemen Sumber Daya Manusia'. Bandung :Alfabeta.

28. Indrawati. (2018). 'Metode Penelitian Kwalitatif Manajemen dan Bisnis Konvergensi Teknologi Informasi dan Komunikasi’. Bandung: PT Refika Aditama .

29. Adikoesoemo (2017).'Manajemen Rumah Sakit, Jakarta'. Pustaka Sinar Harapan

30. Suaedi, F. (2017). 'Pengembangan Kompetensi Sumber Daya Manusia dalam Rangka Meningkatkan Pelayanan di Rumah Sakit Haji Surabaya. Al Tijarah, 3(1), pp.79-102.

31. Peraturan Pemerintah Nomor 67 Tahun 2009 tentang Pengelolaan Tenaga Kesehatan

32. Mathis, R. L., dan J.H. Jackson. (2001). 'Manajemen Sumber Daya Manusia'. buku 1 dan buku 2, Terjemahan. Jakarta: Salemba Empat

33. Moleong \& Lexy J. (2001). Metodelogi Penelitian Kualitatif, Penerbit Remaja Rosdakarya, Bandung.

34. Hasibuan, Sayuti (2000).'Manajemen Sumber Daya Manusia: pendekatan non sekuler'. Muhammadiyah University Press and Magister Manager UMS, Surakarta. 